\title{
RESPONSE OF SOYBEAN YIELD TO LATE SOWING DATES
}

\author{
Soliman', M.M.; E.M. Rabie ${ }^{1}$ and S.B. Ragheb' \\ 1. Field Crops Research Institute, Agriculture Research Center, Giza, Egypt
}

Keywords: Soybean, Yield, Late sowing date

\begin{abstract}
This work conducted on the research farm of Mallawi Agricultural Research Station, El-Minia Province, Egypt, during two successive seasons of 2004 and 2005 to study the role of the late plantings on the productivity of soybean. Three out of four genotypes selected to achieve that goal were new released cultivars, Giza-22; Giza-35; and Giza-111, and the commercial one, Crawford, the common parent of the three genotypes, as control. Three planting dates started on June $1^{\text {st }}$, June $15^{\text {th }}$ for the second date of sowing and ended on June $30^{\text {th }}$ for the third sowing date in both seasons. The package of the recommendations of soybean culture carefully applied to get the best results of each sowing date. The results showed that all of the morphological, yield and productivity traits highly significantly affected by genotype and three out of five morphological traits, number of days to both flowering and maturity and plant height, also highly significantly affected by late sowing date. The other two traits, number of branches and leaf area at 75 days just significantly affected by late sowing date. In terms of yield and its components traits, only seed index highly significantly affected by late sowing date and yield per plot significantly affected by sowing time. All productivity traits were significantly affected by late sowing date specially the content of both oil and protein. Although yield per plot was significantly affected by late sowing date, the yield per plant was not affected by late sowing date indicating that the factor of time of sowing may affect the rate of the germination and control the stand of the plots. Number of active nodules considered as produc-
\end{abstract}

tivity trait because of the residual nitrogen that remain in the soil after harvest for the next crop. This number was significantly affected by sowing time and reached the highest values in the second date of June $15^{\text {th }}$ that may due to the high temperature at this time which lead to increasing the interaction between soybean roots and the nodule bacteria.

\section{INTRODUCTION}

Soybean considered as an important crop of food legumes in Egypt by using its content of protein and oil to decrease their shortages. The productivity of soybean in Egypt is relatively high by following the recommendations package of culture practices. The research can't stop even through breeding programs or through improved the culture practices to improve the productivity of soybean and decrease the production costs. One of these attempts to achieve that target is a comparative study to show the differences between the preferred sowing times that farmers used to in their soybean fields. Farmers in middle Egypt are used to planting soybean after the harvest of wheat in late season started from the half of May and extended to the end of June. It was found that the quality of soybean seeds started to decline due to bad experiences of soybean farmers such as very early planting that leads to elongate the growing season and decrease the viability of produced seeds. Along with very early planting they used to give the second irrigation after about 45 days from sowing, assumed that it would increase the productivity of soybean. Opposite result was found because of nitrogen destructive effect on nodulation and on the whole plants that lead finally to meagre yield and worse quality of seeds. 
Trang, and Giddens (1980) found that both light and temperature are the most important factors affecting growth, nodulation and symbiotic N2fixation by soybeans and hence they affecting seed yield.

In India, Sarbjeet et al (2000) found that soybean yield were higher with sowing on $10^{\text {th }}$ of June than those earlier or later sowings. This investigation aims at studying the effect of late sowings on the productivity under the application of all other recommendations of soybean culture practices.

\section{MATERIALS AND METHODS}

The field experiments conducted at the experimental farm of Mallawi Agricultural Research Station, El-Minia Province, Middle Egypt, during two successive seasons of 2004 and 2005 to study the effect late sowing dates on the productivity of three new released cultivars of soybean, Giza-22, Giza-35 and Giza-111 compared with the old one, Crawford as the parent of them. The descriptions of those genotypes presented in Table (1) show the most important features of the four genotypes. Three planting dates started from last May then half June and ended to last June. The experimental design of the trial was of the split plot type with three replicates occupied a total area of $69.3 \mathrm{~m}^{2}$ representing 1/60.6 of a feddan. Each plot of the experiment involved five rows each is four-meter long and 60 centimeters apart. Seven days before sowing, all plots irrigated to prepare soil for better germination of seeds and give the nodule bacteria the best chance for the process of nodule formation. The characters of number of days to flowering and maturity recorded according to the mean of the plot, leaf area $=\{$ (leaf dry weight per plot $\times$ disk area) / disk dry weight $\}$ were calculated according to the area of disks taken from soybean plants in each plot. The leaf dry weight per plot was calculated according to the mean of 10 plants and times the number of plants in the experimental plot. Number of pods per plant, number of seeds per plant, weight of 100 seeds (Seed Index), plant height, and seed yield per plant recorded according to the mean of ten randomized selected plants at harvest. Data of all traits statistically analyzed according to Sendecor and Cochran (1981) and the means of each treatment compared through the LSD values at both 0.05 and 0.01 levels of probability.
Table 1. The descriptions of soybean genotypes used in this study

\begin{tabular}{|lccccc|}
\hline Genotype & $\begin{array}{c}\text { Ma- } \\
\text { turity } \\
\text { Group }\end{array}$ & $\begin{array}{c}\text { Coun- } \\
\text { try } \\
\text { Origin }\end{array}$ & $\begin{array}{c}\text { Growth } \\
\text { Habit }\end{array}$ & Pedigree \\
\hline 1. Giza-22 & IV & Egypt & Indeter- & Crawford \\
& & & minate & $\times$ Forrest \\
2. Giza.-35 & IV & Egypt & $\begin{array}{r}\text { Indeter- } \\
\text { minate }\end{array}$ & $\begin{array}{c}\text { Crawford } \\
\times \text { Celect }\end{array}$ \\
& & & Indeter- & Crawford \\
3. Giza-111 & IV & Egypt & minate & $\times$ Celect \\
& & & USA & Indeter- & USA \\
4. Crawford & IV & USinate & Origin \\
& & & ming
\end{tabular}

\section{RESULTS AND DISCUSSION}

To show the results in appropriate display, they were divided into three categories of traits. The three categories are: first, five morphological traits of number of days to flowering and maturity, plant height $(\mathrm{cm})$, number of branches per plant and the leaf area at the age of 75 days the time of completing the foliar growth of soybean. Second, are the five traits of yield and its components of number of pods and seeds per plant, seed index (weight of 100 seeds), and weight of seeds per plot. Third, are the five traits of productivity involving seed yield per feddan (ton), number of active nodules at 55 and 75 days from sowing and the contents of protein and oil.

\section{Performance of Morphological Traits}

The data shown in Table (2) reveal the mean performance of some morphological traits under the effect of both treatments and soybean genotypes. It is evident that soybean plants are slightly faster starting flowering in late sowings than in early sowing. There were no large differences between the four genotypes of soybean in flowering trait in which number of days ranged from 32.67 for Giza-35 to 35.67 days for Giza-111. However, number of days to maturity clearly affected by both sowing date and soybean genotypes with six days difference between the first sowing date on June $1^{\text {st }}$ and the last sowing date in June $30^{\text {th }}$ and about eight days between the earliest genotype 
Giza-35 (112.3 days) and the latest matured genotype Giza-111 (120.0 days).

Plant height affected by sowing date in which the difference between the highest value of 96.67 $\mathrm{cm}$ for the first sowing date (June $1^{\mathrm{st}}$ ) and the lowest value of $87 \mathrm{~cm}$ for the third sowing date (June $30^{\text {th }}$ ) reached about $10 \mathrm{~cm}$. The tallest soybean genotype was Giza-111 (96.67 cm) while Giza-35 was the shortest one with value of $83.33 \mathrm{~cm}$. Number of branches reached the highest value in the second sowing date with slightly differences in this trait according to sowing date. However, the differences between soybean genotypes were relatively high in number of branches per plant. The leaf area at the age of 75 days from sowing affected by sowing date and reached the highest value in the first sowing date with value of $2217.4 \mathrm{~cm}^{2}$ and the third sowing date had the lowest value of leaf area at 75 days of sowing. The differences between soybean genotypes in leaf area at 75 days were relatively high in which the highest value $\left(2397.3 \mathrm{~cm}^{2}\right)$ belonged to Giza-22, while Giza-35 had the lowest value of $1573.9 \mathrm{~cm}^{2}$.

Table 2. Performances of morphological traits as affected by sowing date (A) and genotypes of soybean (B).

\begin{tabular}{|c|c|c|c|c|c|}
\hline \multirow[b]{2}{*}{ Factors } & \multicolumn{5}{|c|}{ Morphological Traits } \\
\hline & $\begin{array}{l}\text { No. of } \\
\text { days } \\
\text { to } \\
\text { flow- } \\
\text { ering }\end{array}$ & $\begin{array}{l}\text { No. of } \\
\text { days to } \\
\text { maturity }\end{array}$ & $\begin{array}{l}\text { Plant } \\
\text { height } \\
(\mathrm{cm})\end{array}$ & $\begin{array}{c}\text { No. of } \\
\text { branches } \\
\text { per } \\
\text { plant }\end{array}$ & $\begin{array}{c}\text { Leaf } \\
\text { area at } \\
75 \text { days } \\
\left(\mathrm{cm}^{2}\right)\end{array}$ \\
\hline \multicolumn{6}{|c|}{ A. Sowing date } \\
\hline June $1^{\text {st }}$ & 35.25 & 118.9 & 96.67 & 1.85 & 2217.4 \\
\hline June $15^{\text {th }}$ & 34.75 & 116.0 & 91.92 & 1.97 & 2175.2 \\
\hline June $30^{\text {th }}$ & 34.33 & 112.9 & 87.00 & 1.83 & 1951.4 \\
\hline LSD 0.05 & 0.522 & 0.145 & 1.160 & 0.083 & 404.0 \\
\hline 0.01 & 0.918 & 0.255 & 2.038 & 0.146 & 710.1 \\
\hline \multicolumn{6}{|c|}{ B. Soybean genotypes } \\
\hline 1.Giza-22 & 35.22 & 117.7 & 96.67 & 1.63 & 2397.3 \\
\hline 2.Giza 35 & 32.67 & 112.3 & 83.33 & 1.44 & 1573.9 \\
\hline 3.Giza 111 & 35.67 & 120.0 & 98.33 & 2.92 & 2310.6 \\
\hline 4.Crawford & 35.56 & 113.8 & 89.11 & 1.53 & 2176.8 \\
\hline LSD 0.05 & 0.466 & 0.756 & 2.226 & 0.082 & 57.22 \\
\hline 0.01 & 0.686 & 1.113 & 3.277 & 0.120 & 84.22 \\
\hline
\end{tabular}

The data shown in Table (3) reveal the mean performances of the morphological traits under the effect of the interaction between the two factors of both sowing dates and the genotypes of soybean. Starting with number of days to flowering, this trait ranged from 32.33 to 36.33 for Giza-35 sown in third sowing date of $30^{\text {th }}$ of June and Crawford sown in the first sowing date of $1^{\text {st }}$ of June, respectively. This moderate increasing may be due to the change of day length among sowing dates and the temperature degrees prevailed throughout the season. The number of days to maturity ranged from 110 to 123 days for Giza-35 sown in the third sowing date of $30^{\text {th }}$ of June and Giza-111 sown in the first sowing date of 1 st of June, respectively. Plant height ranged from 78.33 to $103.3 \mathrm{~cm}$ for Giza-35 sown in the third sowing date of $30^{\text {th }}$ of June and Giza-111 sown in the first sowing date of $1^{\text {st }}$ of June, respectively, as the effect on the trait of number of days to maturity.

Table 3. Performances of morphological traits of soybean genotypes under three sowing dates.

\begin{tabular}{|c|c|c|c|c|c|c|}
\hline \multirow[b]{2}{*}{$\begin{array}{l}\text { Sow- } \\
\text { ing } \\
\text { Time }\end{array}$} & \multirow[b]{2}{*}{$\begin{array}{l}\text { Soybean } \\
\text { Genotype }\end{array}$} & \multicolumn{5}{|c|}{ Morphological Traits } \\
\hline & & $\begin{array}{c}\text { No. of } \\
\text { days to } \\
\text { flower- } \\
\text { ing }\end{array}$ & $\begin{array}{l}\text { No. of } \\
\text { days to } \\
\text { maturi- } \\
\text { ty }\end{array}$ & $\begin{array}{l}\text { Plant } \\
\text { height } \\
(\mathrm{cm})\end{array}$ & $\begin{array}{c}\text { No. of } \\
\text { branc } \\
\text { hes } \\
\text { per } \\
\text { plant }\end{array}$ & $\begin{array}{c}\text { Leaf } \\
\text { area at } \\
75 \text { days } \\
\left(\mathrm{cm}^{2}\right)\end{array}$ \\
\hline \multirow{4}{*}{$\begin{array}{c}1^{\text {st }} \\
\text { June }\end{array}$} & 1.Giza-22 & 35.67 & 121.0 & 101.7 & 1.60 & 2523.9 \\
\hline & 2.Giza 35 & 33.00 & 115.0 & 88.33 & 1.40 & 1626.0 \\
\hline & 3.Giza 111 & 36.00 & 123.0 & 103.3 & 2.90 & 2411.6 \\
\hline & 4.Crawford & 36.33 & 116.7 & 93.33 & 1.55 & 2308.3 \\
\hline \multirow{4}{*}{$\begin{array}{l}15^{\text {th }} \\
\text { June }\end{array}$} & 1.Giza-22 & 35.33 & 118.0 & 96.67 & 1.70 & 2536.6 \\
\hline & 2.Giza 35 & 32.67 & 112.3 & 83.33 & 1.53 & 1578.1 \\
\hline & 3.Giza 111 & 35.67 & 120.0 & 98.33 & 3.03 & 2365.8 \\
\hline & 4.Crawford & 35.33 & 114.0 & 89.33 & 1.60 & 2220.4 \\
\hline \multirow{4}{*}{$\begin{array}{l}30^{\text {th }} \\
\text { June }\end{array}$} & 1.Giza-22 & 34.67 & 114.0 & 91.67 & 1.60 & 2131.5 \\
\hline & 2.Giza 35 & 32.33 & 110.0 & 78.33 & 1.40 & 1517.7 \\
\hline & 3.Giza 111 & 35.33 & 117.0 & 93.33 & 2.83 & 2154.6 \\
\hline & 4.Crawford & 35.00 & 110.7 & 84.67 & 1.50 & 2001.8 \\
\hline \multirow[t]{2}{*}{ LSD } & 0.05 & 0.66 & 1.07 & 3.15 & 0.11 & 80.94 \\
\hline & 0.01 & 0.97 & 1.57 & 4.64 & 0.17 & 119.1 \\
\hline
\end{tabular}


Number of branches per plant ranged from 1.4 for Giza-35 sown in the first and third sowing dates to 3.03 for Giza-111 sown in the second sowing time. The leaf area at 75 days, the age of completing the foliar growth of soybean plants, ranged from 1517.7 for Giza-35 sown in the third sowing time to $2523.9 \mathrm{~cm}^{2}$ for Giza-22 sown in the first sowing time. This finding indicates that the performance of the plants grown under the circumstances prevailed through the period for the first sowing time from June $1^{\text {st }}$ to September $15^{\text {th }}$ leads to this increasing in the leaf area.

\section{Significance of the traits}

The data shown in Table (4) reveal the significance of the factors of sowing dates, soybean genotypes and their interactions. Sowing date highly significantly differed in both traits of number of days to maturity and plant height and was just significant in the other three traits of number of days to flowering, number of branches per plant and leaf area at 75 days. However, soybean genotypes highly significantly differed for all morphological traits indicating the high variability between genotypes and giving better opportunity to discriminate the better application of sowing date. The interaction between sowing time and soybean genotypes was just significant in one out five morphological traits, the leaf area at 75 days indicating that the differences in leaf area according to this interaction were significantly high. However, the interactions between sowing date and the other four morphological traits were not significant indicating that the differences between the values of number of days to both flowering and maturity, plant height and number of branches per plant were not significant according to the interaction between sowing date and soybean genotype.

\section{Performance of Yield and its Components Traits}

The data displayed in Table (5) reveal the effect of both factors of treatments and soybean. The highest values of number of pods, number of seeds and yield per plant belonged to the second sowing date (June $15^{\text {th }}$ ) with moderate differences between sowing dates in yield per plot and seed index. The differences between soybean genotypes in the traits of yield and its components are relatively high in which the highest values belonged to both Giza-22 and Giza-111, the most acceptable varieties to the farmers in Middle Egypt.
Table 4. MS values of morphological traits of soybean genotypes under three sowing dates

\begin{tabular}{|c|c|c|c|c|c|c|}
\hline \multirow[b]{2}{*}{$\begin{array}{l}\text { Source of } \\
\text { variance }\end{array}$} & \multirow[b]{2}{*}{ Df } & \multicolumn{5}{|c|}{ MS values of Morphological Traits } \\
\hline & & $\begin{array}{l}\text { No. of } \\
\text { days to } \\
\text { flowering }\end{array}$ & $\begin{array}{l}\text { No. of } \\
\text { days to } \\
\text { maturity }\end{array}$ & $\begin{array}{l}\text { Plant } \\
\text { height } \\
(\mathrm{cm})\end{array}$ & $\begin{array}{c}\text { No. of } \\
\text { branches } \\
\text { per plant }\end{array}$ & $\begin{array}{c}\text { Leaf area } \\
\text { at } 75 \text { days } \\
\left(\mathrm{cm}^{2}\right)\end{array}$ \\
\hline Replicates & 2 & 0.361 & 0.361 & 15.361 & 0.006 & 81248.0 \\
\hline Sowing date(A) & 2 & $2.528^{*}$ & $108.03^{* *}$ & $280.36^{* *}$ & $0.063^{*}$ & $245316.0^{*}$ \\
\hline Error & 4 & 0.361 & 0.028 & 1.778 & 0.009 & 17947.7 \\
\hline Genotype (B) & 3 & $18.148^{* *}$ & $111.44^{* *}$ & $435.81^{* *}$ & $4.371^{* *}$ & $1243740^{* *}$ \\
\hline$A \times B$ & 6 & 0.120 & 0.694 & 0.361 & 0.002 & $17918.2^{*}$ \\
\hline Error & 18 & 0.435 & 1.139 & 9.898 & 0.013 & 6535.8 \\
\hline
\end{tabular}

Table 5. Performances of yield and its components as affected by sowing date (A) and genotypes of soybean (B).

\begin{tabular}{|c|c|c|c|c|c|}
\hline \multirow[b]{2}{*}{ Factors } & \multicolumn{5}{|c|}{ Yield Traits } \\
\hline & $\begin{array}{c}\text { No. } \\
\text { of } \\
\text { pods } \\
\text { per } \\
\text { plant }\end{array}$ & $\begin{array}{c}\text { No. } \\
\text { of } \\
\text { seeds } \\
\text { per } \\
\text { plant }\end{array}$ & $\begin{array}{c}\text { Seed } \\
\text { Index } \\
(100 \\
\text { seeds) }\end{array}$ & $\begin{array}{c}\text { Yield } \\
\text { per } \\
\text { plant } \\
(\mathrm{g})\end{array}$ & $\begin{array}{l}\text { Yield } \\
\text { per } \\
\text { plot } \\
(\mathrm{kg})\end{array}$ \\
\hline \multicolumn{6}{|c|}{ A. Sowing date } \\
\hline June $1^{\text {st }}$ & 76.88 & 207.4 & 17.75 & 36.95 & 3.94 \\
\hline June $15^{\text {th }}$ & 78.00 & 210.5 & 17.16 & 36.44 & 3.87 \\
\hline June $30^{\text {th }}$ & 75.28 & 203.3 & 16.03 & 32.54 & 3.47 \\
\hline LSD 0.05 & 4.03 & 10.94 & 0.062 & 1.66 & 0.21 \\
\hline 0.01 & 7.08 & 19.22 & 0.109 & 2.91 & 0.36 \\
\hline \multicolumn{6}{|c|}{ B. Soybean genotypes } \\
\hline 1.Giza-22 & 84.72 & 228.8 & 17.44 & 39.97 & 4.26 \\
\hline 2.Giza 35 & 65.08 & 172.5 & 15.21 & 26.48 & 2.80 \\
\hline 3.Giza 111 & 88.10 & 233.5 & 16.50 & 38.52 & 4.11 \\
\hline 4.Crawford & 68.99 & 193.2 & 18.77 & 36.28 & 3.87 \\
\hline LSD 0.05 & 2.03 & 5.50 & 0.06 & 1.01 & 0.10 \\
\hline 0.01 & 2.99 & 8.09 & 0.87 & 1.49 & 0.15 \\
\hline
\end{tabular}


Soybean genotypes showed high differences in number of pods, number of seeds, seed index, weight of seeds per plant and weight of seeds per plot in which Giza-22 surpassed all other genotypes in yield and most of its components. Giza35 gave the lowest values of yield and its components that may be due to the meager potential in its seeds to germinate well and the low potential of its plants to perform effectively.

The data shown in Table (6) reveal the performance of the yield and its components traits under the effect of the interaction between the two factors of both the sowing dates and the genotypes of soybean. Starting with number of pods per plant, this trait ranged from 64.93 to 88.57 for Giza-35 sown in third sowing date of $30^{\text {th }}$ of June and Giza-111 sown in both the second and the third sowing dates of $15^{\text {th }}$ and $30^{\text {th }}$ of June, respectively. This difference is due to the high variability between genotypes. The number of seeds per plant ranged from 172.1 to 237.5 seeds for Giza-35 sown in the third sowing date of $30^{\text {th }}$ of June and Giza-22 sown in the second sowing date of $15^{\text {th }}$ of June, respectively. Seed index ranged from 14.70 to 19.60 grams for Giza-35 sown in $30^{\text {th }}$ of June and Crawford sown in the first sowing date of $1^{\text {st }}$ of June. Seed yield per plant ranged from 25.3 for Giza-35 sown in the third time to 42.3 grams for Giza-22 sown in the second time, June $15^{\text {th }}$. The yield of soybean plants per plot ranged from 2.7 for Giza-35 sown in the third time to 4.51 kilograms for Giza-22 sown in the second time, June $15^{\text {th }}$ and that was the exception for Giza-22 that showed very little increase in yield at the second sowing time indicate its high stability in Middle Egypt. The decline of seed yield for Giza-35 may be due to the decreasing of seed viability that may lead to decreasing the germination and resulted in low stand.

\section{Significance of the traits:}

The data shown in Table (7) reveal the significance of the factors of sowing dates, soybean genotypes and their interactions. Sowing date highly significantly differed in just the trait of seed index and was just significant in the trait of leaf area at 75 days. However, soybean genotypes highly significantly differed for all yield and its components traits indicating the high variability between genotypes and giving better opportunity to discriminate the most appropriated sowing date. The interaction between sowing time and soybean genotypes highly significantly differed in just the trait of seed index and was just significant in the trait of yield per plot affirming the compatibility with the effect of the sowing date factor alone.

Table 6. Performances of yield and its component traits of soybean genotypes under three sowing dates

\begin{tabular}{|c|c|c|c|c|c|c|}
\hline \multirow[b]{2}{*}{$\begin{array}{c}\text { Sowing } \\
\text { Time }\end{array}$} & \multirow[b]{2}{*}{$\begin{array}{l}\text { Soybean } \\
\text { Genotype }\end{array}$} & \multicolumn{5}{|c|}{ Yield Traits } \\
\hline & & $\begin{array}{c}\text { No. of } \\
\text { pods } \\
\text { per } \\
\text { plant }\end{array}$ & $\begin{array}{c}\text { No. of } \\
\text { seeds } \\
\text { per } \\
\text { plant }\end{array}$ & $\begin{array}{c}\text { Seed } \\
\text { Index } \\
(100 \\
\text { seeds) }\end{array}$ & $\begin{array}{l}\text { Yield } \\
\text { per } \\
\text { plant }\end{array}$ & $\begin{array}{c}\text { Yield } \\
\text { per plot }\end{array}$ \\
\hline \multirow{5}{*}{$1^{\text {st }}$ June } & 1.Giza-22 & 85.13 & 229.9 & 18.30 & 42.03 & 4.49 \\
\hline & 2.Giza 35 & 65.13 & 172.6 & 15.70 & 27.10 & 2.89 \\
\hline & 3.Giza & 87.17 & 231.0 & 17.40 & 40.20 & 4.29 \\
\hline & 111 & & & & & \\
\hline & $\begin{array}{l}\text { 4.Crawfo } \\
\text { rd }\end{array}$ & 70.10 & 196.3 & 19.60 & 38.47 & 4.10 \\
\hline \multirow{5}{*}{$15^{\text {th }}$ June } & 1.Giza-22 & 87.97 & 237.5 & 17.80 & 42.30 & 4.51 \\
\hline & 2.Giza 35 & 65.17 & 172.7 & 15.23 & 27.03 & 2.81 \\
\hline & 3.Giza & 88.57 & 234.7 & 16.80 & 39.40 & 4.21 \\
\hline & 111 & & & & & \\
\hline & $\begin{array}{l}\text { 4.Crawfo } \\
\text { rd }\end{array}$ & 70.30 & 196.9 & 18.80 & 37.03 & 3.95 \\
\hline \multirow{5}{*}{$30^{\text {th }}$ June } & 1.Giza-22 & 81.07 & 218.9 & 16.23 & 35.57 & 3.79 \\
\hline & 2.Giza 35 & 64.93 & 172.1 & 14.70 & 25.30 & 2.70 \\
\hline & 3.Giza & 88.57 & 234.7 & 15.30 & 35.67 & 3.83 \\
\hline & 111 & & & & & \\
\hline & $\begin{array}{l}\text { 4. Craw- } \\
\text { ford }\end{array}$ & 66.57 & 186.4 & 17.90 & 33.33 & 3.56 \\
\hline \multirow[t]{2}{*}{ LSD } & 0.05 & 2.87 & 7.77 & 0.09 & 1.43 & 0.14 \\
\hline & 0.01 & 4.23 & 11.44 & 0.13 & 2.10 & 0.21 \\
\hline
\end{tabular}

Table 7. MS values of yield and its component traits of soybean genotypes under three sowing dates.

\begin{tabular}{|c|c|c|c|c|c|c|}
\hline \multirow[b]{2}{*}{$\begin{array}{l}\text { Source of } \\
\text { variance }\end{array}$} & \multirow[b]{2}{*}{ df } & \multicolumn{5}{|c|}{ MS values of Morphological Traits } \\
\hline & & $\begin{array}{c}\text { No. of } \\
\text { pods per } \\
\text { plant }\end{array}$ & $\begin{array}{c}\text { No. of } \\
\text { seeds per } \\
\text { plant }\end{array}$ & $\begin{array}{c}\text { Seed } \\
\text { Index (100 } \\
\text { seed })\end{array}$ & $\begin{array}{c}\text { Yield per } \\
\text { plant }\end{array}$ & $\begin{array}{c}\text { Yield per } \\
\text { plot }\end{array}$ \\
\hline Replicates & 2 & 103.80 & 761.3 & 0.041 & 25.77 & 0.256 \\
\hline Sowing date(A) & 2 & 22.374 & 167.4 & $9.125^{3 *}$ & 69.80 & $0.771^{*}$ \\
\hline Error & 4 & 21.451 & 157.712 & 0.005 & 3.621 & 0.057 \\
\hline Genotype (B) & 3 & $1166.55^{* *}$ & $7673.0^{* *}$ & $20.302^{* *}$ & $332.84^{* *}$ & $3.923^{* *}$ \\
\hline$A \times B$ & 6 & 9.651 & 71.6 & $0.265^{* *}$ & 4.385 & $0.057^{*}$ \\
\hline Error & 18 & 8.244 & 60.27 & 0.007 & 2.030 & 0.021 \\
\hline
\end{tabular}




\section{Performance of Productivity Traits}

The data shown in Table (8) reveal the mean performances of the productivity traits under the effect of both factors of treatments and the genotypes of soybean. The first sowing date (June $1^{\text {st }}$ ) resulted in the highest values of yield per feddan, number of nodules at 75 days and the oil content followed by the second sowing date (June $15^{\text {th }}$ ) in which the protein content exceeded the first sowing date. The value of protein content in the third sowing date (June $30^{\text {th }}$ ) surpassed those belonged to the other sowing dates affirming that protein content increases in seeds from late sowed plants.

Table 8. Performance of the productivity traits as affected by sowing dates (A) and genotypes of soybean (B).

\begin{tabular}{|c|c|c|c|c|c|}
\hline \multirow[b]{2}{*}{ Factors } & \multicolumn{5}{|c|}{ Productivity Traits } \\
\hline & $\begin{array}{l}\text { Yield } \\
\text { per } \\
\text { fed- } \\
\text { dan } \\
\text { (Ton) }\end{array}$ & $\begin{array}{c}\text { Nodules } \\
\text { at } 55 \\
\text { days }\end{array}$ & $\begin{array}{c}\text { Nodules } \\
\text { at } 75 \\
\text { days }\end{array}$ & $\begin{array}{c}\% \text { of } \\
\text { protein }\end{array}$ & $\begin{array}{l}\% \text { of oil } \\
\text { content }\end{array}$ \\
\hline \multicolumn{6}{|c|}{ A. Sowing date } \\
\hline June $1^{\text {st }}$ & 1.725 & 15.70 & 27.38 & 36.05 & 21.52 \\
\hline June $15^{\text {th }}$ & 1.692 & 15.83 & 26.87 & 36.73 & 20.50 \\
\hline June $30^{\text {th }}$ & 1.518 & 13.80 & 24.09 & 37.46 & 19.23 \\
\hline LSD 0.05 & 0.09 & 0.83 & 1.45 & 0.25 & 0.17 \\
\hline 0.01 & 0.16 & 1.45 & 2.55 & 0.44 & 0.30 \\
\hline \multicolumn{6}{|c|}{ B. Soybean genotypes } \\
\hline 1.Giza-22 & 1.856 & 16.97 & 29.60 & 35.37 & 21.33 \\
\hline 2.Giza 35 & 1.224 & 11.13 & 19.46 & 36.50 & 20.52 \\
\hline 3.Giza 111 & 1.797 & 16.34 & 28.52 & 36.31 & 19.43 \\
\hline 4.Crawford & 1.693 & 15.40 & 26.88 & 38.80 & 20.38 \\
\hline LSD 0.05 & 0.05 & 0.41 & 0.70 & 0.24 & 0.14 \\
\hline 0.01 & 0.07 & 0.60 & 1.02 & 0.35 & 0.20 \\
\hline
\end{tabular}

The data shown in Table (9) reveal the mean performances of the productivity traits under the effect of the interaction between the two factors of both sowing dates and genotypes of soybean. Starting with yield per feddan trait ranged from 1.181 to 1.973 ton for Giza-35 sown in third sowing date of $30^{\text {th }}$ of June and Giza-22 sown in the second sowing date of $15^{\text {th }}$ of June, respectively. Because the value of this trait was derived from the trait of yield per plot, the same explanation of why Giza-22 had the exception of increasing its yield in the second sowing date of June $15^{\text {th }}$ and it was found that there was another reason. This reason was due to its ability of forming high number of nodules, 17.97 at 55 days and 31.33 nodules per plant at 75 days, in the second sowing date of $15^{\text {th }}$ of June. The number of nodules per plant ranged from 10.73 nodules at 55 days and increased to 18.77 nodules at 75 days for Giza-35 sown in the third sowing date to 17.97 nodules at 55 days and increased to 31.33 nodules at 75 days for Giza-22 sown in the second sowing date of $15^{\text {th }}$ of June. The traits of protein and oil content were in contrary relationships. That is, while the protein increase in late sowing the oil decrease in the same time. The protein content ranged from $34.56 \%$ for Giza-22 sown in $1^{\text {st }}$ of June to $39.28 \%$ for Crawford sown in $30^{\text {th }}$ of June. However, oil content ranged from $18.27 \%$ for Giza-111 sown in $30^{\text {th }}$ of June to $22.3 \%$ for Giza-22 sown in $1^{\text {st }}$ of June. This relationship between both traits of protein and oil contents according to the sowing date give the opportunity to make precise decision to the purpose of sowing soybean at specific times. These findings affirming the suitability of sowing both new released cultivars, Giza-22 and Giza111, as they considered the most appropriate genotypes possessing acceptable characters, encouraging farmers to grow them in Middle Egypt.

Table 9. Performances of productivity traits of soybean genotypes under three sowing dates.

\begin{tabular}{|c|c|c|c|c|c|c|}
\hline \multirow[b]{2}{*}{$\begin{array}{c}\text { Sowing } \\
\text { Time }\end{array}$} & \multirow[b]{2}{*}{$\begin{array}{l}\text { Soybean } \\
\text { Genotype }\end{array}$} & \multicolumn{5}{|c|}{ Morphological Traits } \\
\hline & & $\begin{array}{l}\text { Yield } \\
\text { per } \\
\text { feddan } \\
\text { (Ton) }\end{array}$ & $\begin{array}{c}\text { Nodules } \\
\text { at } 55 \\
\text { days }\end{array}$ & $\begin{array}{c}\text { Nodules } \\
\text { at } 75 \\
\text { days }\end{array}$ & $\begin{array}{l}\% \text { of } \\
\text { pro- } \\
\text { tein }\end{array}$ & $\begin{array}{c}\% \text { of } \\
\text { oil } \\
\text { content }\end{array}$ \\
\hline \multirow{4}{*}{$1^{\text {st } J u n e ~}$} & 1.Giza-22 & 1.963 & 17.87 & 31.17 & 34.56 & 22.36 \\
\hline & 2.Giza 35 & 1.265 & 11.50 & 20.10 & 35.62 & 21.91 \\
\hline & 3.Giza 111 & 1.876 & 17.07 & 29.77 & 35.71 & 20.54 \\
\hline & 4.Crawford & 1.795 & 16.37 & 28.50 & 38.44 & 21.42 \\
\hline \multirow{4}{*}{$\begin{array}{l}15^{\text {th }} \\
\text { June }\end{array}$} & 1.Giza-22 & 1.973 & 17.97 & 31.33 & 35.26 & 21.43 \\
\hline & 2.Giza 35 & 1.228 & 11.17 & 19.50 & 36.45 & 20.36 \\
\hline & 3.Giza 111 & 1.840 & 16.70 & 29.20 & 36.52 & 19.65 \\
\hline & 4.Crawford & 1.727 & 15.70 & 27.43 & 38.55 & 20.72 \\
\hline \multirow{4}{*}{$\begin{array}{l}30^{\text {th }} \\
\text { June }\end{array}$} & 1.Giza-22 & 1.658 & 15.07 & 26.30 & 36.46 & 20.34 \\
\hline & 2.Giza 35 & 1.181 & 10.73 & 18.77 & 37.53 & 19.43 \\
\hline & 3.Giza 111 & 1.676 & 15.27 & 26.60 & 36.72 & 18.27 \\
\hline & 4.Crawford & 1.557 & 14.13 & 24.70 & 39.28 & 19.18 \\
\hline \multirow[t]{2}{*}{ LSD } & 0.05 & 0.06 & 0.58 & 0.98 & 0.34 & 0.19 \\
\hline & 0.01 & 0.09 & 0.85 & 1.45 & 0.50 & 0.29 \\
\hline
\end{tabular}




\section{Significance of the traits}

The data shown in Table (10) reveal the significance of sowing dates, soybean genotypes and their interactions. Sowing date applications highly significantly differed in both traits of protein and oil content and was just significant in the other three traits yield per feddan, number of nodules per plant at both 55 and 75 days. However, soybean genotypes highly significantly differed for all productivity traits indicating the high variability between genotypes and giving better opportunity to discriminate the better applying sowing date. The interaction between sowing time and soybean genotypes was highly significant in just one out five productivity traits, the oil content indicating that the differences in oil content according to this interaction were significantly high. However, the interactions between sowing date and soybean genotype for the other four traits were significant indicating that the differences between the values of yield per feddan, number of nodules per plant at two ages of 55 and 75 days and protein content were significant.

Table 10. MS values of productivity traits of soybean genotypes under three sowing dates.

\begin{tabular}{|c|c|c|c|c|c|c|}
\hline \multirow[b]{2}{*}{$\begin{array}{l}\text { Source of vari- } \\
\text { ance }\end{array}$} & \multirow[b]{2}{*}{$\mathrm{df}$} & \multicolumn{5}{|c|}{ MS values of productivity Traits } \\
\hline & & $\begin{array}{l}\text { Yield } \\
\text { per } \\
\text { feddan } \\
\text { (Ton) }\end{array}$ & $\begin{array}{c}\text { Nodules } \\
\text { at } 55 \\
\text { days }\end{array}$ & $\begin{array}{c}\text { Nodules } \\
\text { at } 75 \\
\text { days }\end{array}$ & $\begin{array}{c}\% \text { of } \\
\text { protein }\end{array}$ & $\begin{array}{l}\% \text { of oil } \\
\text { content }\end{array}$ \\
\hline Replicates & 2 & 0.049 & 3.951 & 12.387 & 0.069 & 0.032 \\
\hline Sowing date (A) & 2 & $0.148^{*}$ & $12.434^{*}$ & $37.605^{*}$ & $5.954^{* *}$ & $15.703^{* *}$ \\
\hline Error & 4 & 0.011 & 0.894 & 2.775 & 0.084 & 0.038 \\
\hline Genotype (B) & 3 & $0.752^{* *}$ & $62.341^{* *}$ & $188.61^{* *}$ & $19.113^{* *}$ & $5.460^{* *}$ \\
\hline $\mathrm{A} \times \mathrm{B}$ & 6 & $0.011^{*}$ & $0.932^{*}$ & $2.778^{*}$ & $0.303^{*}$ & $0.149^{* *}$ \\
\hline Error & 18 & 0.004 & 0.331 & 0.965 & 0.116 & 0.037 \\
\hline
\end{tabular}

The physical factors affecting the environment according to sowing time are daily temperature and light intensity. Soil temperature is known to have varying the impact on nodulation and nitrogen fixation of strains of Rhizobium Dart and Mercer (1965). Strains of $R$. japonicum should be selected for growing areas where soil temperature favor their establishment, and might better be introduced into the soil during periods that are optimum for their colonization. The day light time prevailed at the region of this investigation was surveyed throughout the growing season from the beginning of June (day length $=11$ hours and 45 minutes) to the first of October (day length $=11$ hours and 27 minutes) with no sharp change in the temperatures. These two factors affected the photosynthesis process, the major factor limiting nitrogen fixation by soybean and other legume crops Hardy and Havelka (1975). The results obtained were in concordance with those of Borad \& Hall (1984); Borad (1985); Moore \& Hartwig (1991); Ali (1993); Mohamed (1994); Sarbjeet et al (2000) and Hassan et al (2002).

\section{REFERENCES}

Ali, Kh.A.M. (1993). Response of Some New Early Maturing Soybean Genotypes to Planting Dates and Plant Population Densities. pp. 8596. Ph.D. Thesis, Faculty of Agric., Cairo Univ., Egypt.

Borad, J.E. and W. Hall (1984). Premature flowering in soybean yield reduction at non optimal planting dates as influenced by temperature and photoperiod. Agron. J., 76(4): 700-704.

Borad, J.E. (1985). Yield components associated with soybean yield reduction at non optimal planting dates. Agron. J., 77(1): 135-140.

Dart, P.J. and F.V. Mercer (1965). The effect of temperature, level of ammonium nitrate and light intensity on the growth of nodulation of cowpea (Vigna sinensis Endl. Ex. Hassk.) Austr. J. Agric. Res., 16: 321-345.

Hardy, R.W. and V.D. Havelka (1975). Photosynthesis as a major factor limiting nitrogen fixation by field-grown legumes with emphasis on soybean. In: Symbiotic Nitrogen Fixation in Plants. pp. 85-99. Nutman, O.S. (ed.), Cambridge Univ. Press.

Hassan, M.Z.; Kh.A. Al-Assily; M.S.A. Mohamed and A.E. Sharaf (2002). Performance of some soybean cultivars under different sowing dates at newly recalaimed lands of East Owinat and Kharga. Arab Univ. J. Agric. Sci. Ain Shams Univ., Cairo, 10 (1): 173-179.

Mohamed, M.S.A. (1994). Evaluation of Some Soybean Genotypes at Different Population Densities Under Optimum and Late Sowing. pp 
74-93. Ph.D. Thesis, Fac. of Agric. Moshtoher, Zagazig Univ., Egypt.

Moore, S.M.; E.E. Hartwig and C.A. Evans (1991). Increasing soybean yields at early and late planting dates by delayed flowering. Louisiana Agric. 34 (3): 4-5

Sarbjeet Singh; Singh Kulvir and D.S. Kler (2000). Influence of planting time and plant geometry density on periodic dry matter accumula- tion and seed yield of soybean (Glycine max L.). Crop Research, Hisar, 20 (1): 76-80.

Sendecor, G.W. and W.G. Cochran (1981). Statistical Methods. Seventh Edition. Iowa State Univ. Press, Ames, Iowa, USA.

Trang, K.M. and J. Giddens (1980). Shading and temperature as environmental factors affecting growth, nodulation and symbiotic N2-fixation by soybeans. Agron. J., 72: 305-308. 